\title{
In vivo nuclear translocation of mineralocorticoid and glucocorticoid receptors in rat kidney: differential effect of corticosteroids along the distal tubule
}

\author{
Daniel Ackermann, ${ }^{1,2}$ Nikolay Gresko, ${ }^{3}$ Monique Carrel, ${ }^{3}$ Dominique Loffing-Cueni, ${ }^{3}$ Daniel Habermehl, ${ }^{4}$ \\ Celso Gomez-Sanchez, ${ }^{5}$ Bernard C. Rossier, ${ }^{6}$ and Johannes Loffing ${ }^{1,3}$ \\ ${ }^{1}$ Unit of Anatomy, Department of Medicine, University of Fribourg, Fribourg; ${ }^{2}$ Clinic for Nephrology and Hypertension, \\ University Hospital of Bern, Bern; ${ }^{3}$ Institute for Anatomy, University of Zürich, Zürich; ${ }^{4}$ German Cancer Research Center, \\ Heidelberg, Germany; ${ }^{5}$ Department for Endocrinology, G. V. (Sonny) Montgomery Veterans Affairs Medical Center, \\ University of Mississippi, Jackson, Mississippi; and ${ }^{6}$ Department of Pharmacology and Toxicology, University of Lausanne, \\ Lausanne, Switzerland
}

and corticosterone bind to mineralocorticoid (MR) and glucocorticoid receptors (GR), which, upon ligand binding, are thought to translocate to the cell nucleus to act as transcription factors. Mineralocorticoid selectivity is achieved by the $11 \beta$-hydroxysteroid dehydrogenase type 2 (11ß-HSD2) that inactivates $11 \beta$-hydroxy glucocorticoids. High expression levels of $11 \beta$-HSD2 characterize the aldosterone-sensitive distal nephron (ASDN), which comprises the segment-specific cells of late distal convoluted tubule (DCT2), connecting tubule (CNT), and collecting duct (CD). We used MR- and GR-specific antibodies to study localization and regulation of MR and GR in kidneys of rats with altered plasma aldosterone and corticosterone levels. In control rats, MR and GR were found in cell nuclei of thick ascending limb (TAL), DCT, CNT, CD cells, and intercalated cells (IC). GR was also abundant in cell nuclei and the subapical compartment of proximal tubule (PT) cells. Dietary $\mathrm{NaCl}$ loading, which lowers plasma aldosterone, caused a selective removal of GR from cell nuclei of $11 \beta$ HSD2-positive ASDN. The nuclear localization of MR was unaffected. Adrenalectomy (ADX) resulted in removal of MR and GR from the cell nuclei of all epithelial cells. Aldosterone replacement rapidly relocated the receptors in the cell nuclei. In ASDN cells, low-dose corticosterone replacement caused nuclear localization of MR, but not of GR. The GR was redistributed to the nucleus only in PT, TAL, early DCT, and IC that express no or very little $11 \beta$-HSD2. In ASDN cells, nuclear GR localization was only achieved when corticosterone was replaced at high doses. Thus ligand-induced nuclear translocation of MR and GR are part of MR and GR regulation in the kidney and show remarkable segment- and cell type-specific characteristics. Differential regulation of MR and GR may alter the level of heterodimerization of the receptors and hence may contribute to the complexity of corticosteroid effects on ASDN function.

aldosterone; corticosterone; $11 \beta$-hydroxysteroid dehydrogenase type 2

THE MINERALOCORTICOID RECEPTOR (MR) and the glucocorticoid receptor (GR) mediate the effects of corticosteroids in virtually all organs, including the brain, heart, lung, and kidney. Renal MR- and GR-dependent signaling is involved in the control of electrolyte transport (56) and regulation of cell metabolism

Address for reprint requests and other correspondence: J. Loffing, Univ. of Zurich, Institute of Anatomy and Zurich Centre for Integrative Human Physiology, Winterthurerstrasse 190, CH-8057 Zurich, Switzerland (e-mail: johannes.loffing@anatom.uzh.ch). including gluconeogenesis and ammoniagenesis (30). Studies on gene-modified mice confirmed the pivotal physiological relevance of both receptors. MR- and GR-deficient mice die shortly after birth due to severe salt wasting or impaired lung maturation, respectively $(3,6)$.

The MR and the GR are ligand-dependent transcription factors, that share high homologies in the DNA- and ligandbinding domains, and which have distinct affinities for corticosteroid hormones (57). While the affinity of the MR for aldosterone and physiological glucocorticoids (i.e., corticosterone in rodent and cortisol in human) is high ( $K_{\mathrm{d}}$ in the range from 0.5 to $3 \mathrm{nM}$ ), the GR has $>10$ times lower affinity for these steroids ( $K_{\mathrm{d}}$ in the range from 20 to $65 \mathrm{nM}$ ) (1). Ligand-binding induces a dimerization of the receptors, which is thought to be followed by the translocation of the receptorligand complex to the cell nucleus where it then binds to specific MR- and GR-dependent response elements in the promoter regions of target genes (56). MR and GR may not only form homodimers (MR-MR or GR-GR) but also heterodimers (MR-GR), which may differentially activate or repress gene networks and hence may contribute to the significant complexity of MR- and GR-dependent signaling (14).

Because physiological glucocorticoids circulate in the blood plasma at 100-1,000 times higher concentrations than aldosterone, mammalian species had to develop mechanisms to provide mineralocorticoid specificity to target cells (14). One major mechanism that evolved and protects the MR and GR from glucocorticoid access is mediated by the enzyme $11 \beta$ hydroxysteroid dehydrogenase type 2 (11ß-HSD2), which rapidly metabolizes physiological glucocorticoids into metabolites that have weak or no affinity for the receptors. Accordingly, tissues with high aldosterone responsiveness are characterized by high expression levels of $11 \beta-\operatorname{HSD} 2(4,14,56)$. Within the rodent kidney, $11 \beta-H S D 2$ is highly abundant in the late distal convoluted tubule (DCT2), the connecting tubule (CNT), and the collecting duct (CD) (4), which hence form the so-called aldosterone-sensitive distal nephron (ASDN) (36). Along the ASDN, aldosterone stimulates sodium reabsorption via activation of the epithelial sodium channel $(\mathrm{ENaC})$ and the Na-KATPase that are expressed in the apical and basolateral plasma membrane of the ASDN cells, respectively (56).

Although the function of mineralo- and glucocorticoids as well as their receptors appears to be well established and several studies addressed the localization of MR and GR along the mammalian nephron, the precise cellular and subcellular 
localization of MR and GR in specific nephron portions and cell types under normal and steroid-stimulated conditions are still unclear. Immunohistochemical, hormone binding, and RTPCR studies revealed the MR unambiguously along the ASDN $(4,7,10,13,32,37,45,53)$, but MR localization in upstream nephron portions such as the thick ascending limb (TAL) is less clear. Similarly, a convincing demonstration of MR expression in intercalated cells in the kidney in vivo is lacking. So far, only some expression data on immunoisolated cells from rabbit CD suggested the expression of the MR in principal cells and at least some subtypes of intercalated cells (40). However, immunohistochemical studies failed to detect MR in intercalated cells in the collecting system of rat kidneys $(4,13)$. In addition to the ambiguities regarding the cellular distribution of MR and GR, little is known about the corticosteroiddependent regulation of MR and GR in the kidney in vivo. Nuclear translocation of the MR upon ligand binding has been well documented in in vitro systems (16), but an in vivo demonstration of this effect in the kidney is lacking. In fact, previous studies did not detect any substantial effect of corticosteroid dosing on the subcellular localization of MR and GR in renal epithelial cells in vivo $(13,32,37)$.

Therefore, the aim of the present study was to reinvestigate the cellular localization of MR and GR along the rat nephron and to study the regulation of the subcellular localization of MR and GR in response to altered corticosteroid hormone levels by using a set of highly specific antibodies against MR and GR.

\section{MATERIALS AND METHODS}

Animal experiments. Animal studies were conducted in accordance with Swiss animal welfare regulations and after written consent of the veterinarian office of the Canton of Fribourg, Switzerland. Kidneys were harvested from 1) 6- to 8-wk-old male transgenic $\mathrm{MR}^{\mathrm{AQP} 2 \mathrm{cre}}$ mice with targeted deletion of the MR in the segment-specific cells of the CD and late CNT (46), 2) from male newborn GR-deficient mice with targeted deletion of GR in all cell types (6), and 3) from male 6- to 8-wk-old Wistar rats (Charles River Laboratories, Elevage Janvier, France). Mice and rats had free access to tap water and were fed with a standard laboratory chow containing $0.3 \%$ sodium.

Three different types of experiments were performed: experiment 1 , where rats received either a standard diet (Control, $\left.0.3 \% \mathrm{Na}^{+}\right)$or a high-sodium $\left(5 \% \mathrm{Na}^{+}\right)$diet for 5 days $\left(\mathrm{High} \mathrm{Na}^{+}\right)$; experiment 2 , where rats were adrenalectomized and received either only an intravenous infusion of vehicle (ADX) or of a physiologically relevant concentration of aldosterone $\left(1 \mu \mathrm{g} \cdot \mathrm{kg}\right.$ body $\left.\mathrm{wt}^{-1} \cdot \mathrm{h}^{-1} ; \mathrm{ADX}+\mathrm{Aldo}\right)$, and the vehicle and aldosterone were infused with a perfusor for $4 \mathrm{~h}$ starting 2 days after adrenalectomy; and experiment 3 , where rats were adrenalectomized and received either a subcutaneous infusion of vehicle (ADX), low-dose corticosterone $\left(1 \mu \mathrm{g} \cdot \mathrm{kg}\right.$ body $\mathrm{wt}^{-1} \cdot \mathrm{h}^{-1}$; ADX + Low Cortico), or high-dose corticosterone $(100 \mu \mathrm{g} \cdot \mathrm{kg}$ body $\mathrm{wt}^{-1} \cdot \mathrm{h}^{-1}$; ADX + High Cortico). Vehicle and corticosterone were infused via osmotic minipumps for two days starting immediately after ADX. At least five rats per group were studied.

For ADX, animals were anesthetized with a mixture $(450 \mu \mathrm{l} / \mathrm{kg}$ body wt ip) containing Dormitor ( $1 \mathrm{mg} / \mathrm{ml}$, Pfizer, Karlsruhe, Germany), Climasol (10 mg/ml, Gräub, Bern, Switzerland), and Fentanyl $(0.5 \mathrm{mg} / \mathrm{ml}$, Janssen Cilag, Baar, Switzerland). Bilateral ADX was performed. After surgery, rats were awakened with a mixture $(680$ $\mu \mathrm{l} / \mathrm{g}$ body wt sc) containing Antisedan ( $1 \mathrm{mg} / \mathrm{ml}$, Pfizer), Sarmasol (1 $\mathrm{mg} / \mathrm{ml}$, Gräub), and Narcan $(0.4 \mathrm{mg} / \mathrm{ml}$, Opopharma, Zurich, Swit- zerland). All animals received a nonsteroidal pain killer subcutaneously intraoperatively.

For intravenous aldosterone application, the rats were anesthetized with the same mixture as for ADX. Surgical preparation included cannulation of the jugular vein and suprapubic cannulation of the urinary bladder for urine collection. Urine was collected for the last 15 min of every full hour. After cannulation of the jugular vein, an intravenous infusion with $0.9 \% \mathrm{NaCl}$ was started at the rate of 0.72 $\mathrm{ml} \cdot \mathrm{kg}^{-1} \cdot \mathrm{min}^{-1}$ for $30 \mathrm{~min}$ and then maintained at the rate of 0.36 $\mathrm{ml} \cdot \mathrm{kg}^{-1} \cdot \mathrm{min}^{-1}$ for the rest of the experiment. For the aldosteronetreated rats, 45 min after the infusion was started urine was collected for $15 \mathrm{~min}$ (end of the control period). One hour after the start of the infusion, aldosterone (Sigma-Aldrich, Epalinges, Switzerland) was added to the solution at a concentration of $129 \mathrm{nmol} / \mathrm{l}(46 \mu \mathrm{g} / \mathrm{l})$, resulting in a constant delivery of $1 \mu \mathrm{g} \cdot \mathrm{kg}$ body $\mathrm{wt}^{-1} \cdot \mathrm{h}^{-1}$. Animals were killed $3 \mathrm{~h}$ after starting the aldosterone treatment. Control animals were treated for $4 \mathrm{~h}$ with $0.9 \% \mathrm{NaCl}$ only.

Animals of the corticosterone-treated groups received an osmotic minipump (Alzet, Charles River) during the adrenalectomy that delivered a constant rate of corticosterone (Sigma-Aldrich) solved in $0.9 \% \mathrm{NaCl}$ for the following days. Control animals received the vehicle only. The physiological effects of corticosterone were studied in a different series of animals that were prepared according to the same protocol and administered the same amounts of corticosterone or carrier solution. Animals were kept in individual metabolic cages for $24 \mathrm{~h}$ before adrenalectomy and death, respectively. Urinary sodium and potassium concentrations in the collected samples were measured using an ion-selective electrode provided by Roche Diagnostics. We did not take any blood samples from the rats as previous experiments showed that this compromises tissue perfusion fixation likely due to hypovolemic vasoconstriction.

$R T-P C R$ on mouse microdissected tubules. Isolated tubules were obtained by microdissection. After anesthesia (thiopental, $5 \mathrm{mg} / 100 \mathrm{~g}$ body wt), the left kidney was perfused with liberase blendzyme II (40 $\mu \mathrm{g} / \mathrm{ml}$, Roche, Basel, Switzerland) dissolved in DMEM-F12 (GIBCO, Basel, Switzerland). Thin pyramids cut along the corticomedullary axis were incubated for $30 \mathrm{~min}$ at $37^{\circ} \mathrm{C}$ and $5 \% \mathrm{CO}_{2}$ in the DMEMF12 containing $40 \mu \mathrm{g} / \mathrm{ml}$ liberase. The pyramids were then rinsed in the microdissection solution and kept on ice. The segments were microdissected at $4^{\circ} \mathrm{C}$ under stereomicroscopic observation in the same medium (DMEM-F12). Glomeruli, PCT, and proximal straight tubules, outer medullary and cortical TAL, DCT, CNT, and the different parts of the CD were isolated. Total RNA were extracted from 25 isolated glomeruli and $20 \mathrm{~mm}$ of each nephron segment. Isolation of tubule RNA was performed according to the standard TRIzol method protocol (Invitrogen). RT was performed using Superscript II (Invitrogen) with $4 \mu \mathrm{l}$ of $5 \times \mathrm{RT}$ buffer, $1 \mu \mathrm{l}$ of $50 \mu \mathrm{M}$ random hexamers (Applied Biosystems, Foster City, CA), $1 \mu l 20$ mM dNTP (Promega, Wallisellen, Switzerland), and $4 \mu \mathrm{l}$ of tubule RNA diluted in $\mathrm{H}_{2} \mathrm{O}$ (up to $20 \mu \mathrm{l}$ ). For analysis of MR expression along the nephron, standard PCR was carried out on $25 \%$ of the total amount of RT product from $20 \mathrm{~mm}$ of each isolated nephron segment. MR and $\beta$-actin primers were used as previously described $(3,8)$. For GR, the following primers were applied: 5'-GAAAGCATTGCAAACCTCAA- ${ }^{\prime}$ and $5^{\prime}$-TCTGTTTTCACTGGGGCA- ${ }^{\prime}$. The following conditions for the PCR were used: annealing temperature $60^{\circ} \mathrm{C}$; annealing time $1 \mathrm{~min}$; elongation temperature $72^{\circ} \mathrm{C}$; elongation time $45 \mathrm{~s} ; 35$ cycles. Total volume of PCR was loaded on a $1 \%$ agarose gel; electrophoresis was done for $30 \mathrm{~min}$ (constant $80 \mathrm{~V}$ ).

Western blot analysis. mCCD cells were grown on collagen-treated semipermeable support (Transwell, Corning Costar, Cambridge, MA) (19). For GR detection, cells were lysed in $100 \mu$ l lysis buffer [150 $\mathrm{mM} \mathrm{NaCl}, 50 \mathrm{mM}$ Tris. $\mathrm{HCl}(\mathrm{pH} \mathrm{8),} 1 \%$ Triton X-100, $0.5 \mathrm{mM}$ 2-aminoethylbenzenesulfonyl fluoride (Pefabloc; Roche)]. Fifty micrograms of total protein was separated by SDS-PAGE and blotted on a nitrocellulose membrane. For MR detection, cells were lysed in buffer containing $0.12 \mu \mathrm{M}$ molybdate. Homogenized cells were then 


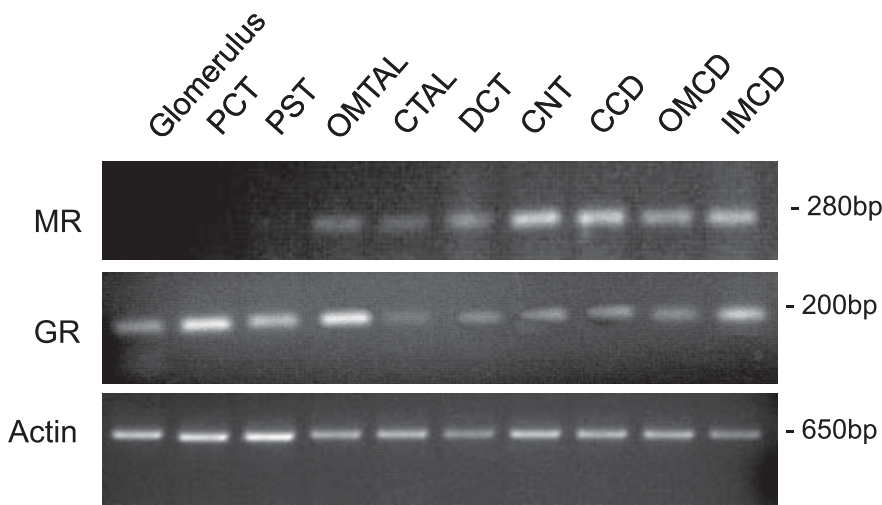

Fig. 1. Distribution of mRNA encoding for mineralocorticoid (MR) and glucocorticoid receptors (GR) along the mouse nephron. RT-PCR was performed on microdissected nephron portions. Glomeruli, proximal convoluted and straight tubules (PCT, and PST, respectively), outer medullary and cortical thick ascending limbs (OMTAL and CTAL, respectively), distal convoluted tubules (DCT), connecting tubules $(\mathrm{CN})$, and cortical, outer medullary, and inner medullary collecting ducts $(\mathrm{CCD}, \mathrm{OMCD}$, and IMCD, respectively) were microdissected from murine kidney; mRNA was isolated from 25 glomeruli and $20 \mathrm{~mm}$ of nephron segment each. RT-PCR was performed using primers specific for MR, GR and actin as described in MATERIALS AND METHODS. The amplified fragments were verified by sequencing. Detection of actin mRNA was used as a control.

centrifuged for $20 \mathrm{~min}$ at $20,000 \mathrm{~g}$ to accumulate cytosolic proteins in the supernatant. Fifty micrograms of the cytosolic protein fraction was further separated by SDS-PAGE and blotted on a nitrocellulose membrane.

After transfer, membranes were incubated for $1 \mathrm{~h}$ in blocking solution (5\% low-fat milk in TBS- $0.04 \%$ Tween) to block unspecific binding sites. The primary antibodies were applied for $16 \mathrm{~h}$ at $4{ }^{\circ} \mathrm{C}$. Subsequently, the membranes were incubated for $2 \mathrm{~h}$ at room temperature with the secondary horseradish peroxidase-labeled anti-rabbit and anti-mouse antibodies, respectively. Chemiluminescence detection (enhanced ECL detection kit, Amersham) was used to visualize antibody-binding on X-ray film. All antibodies were diluted in blocking solution [MR: rMR1-18 (24) 1:500; GR: M-20 (sc-1004, 1:2,000, Santa Cruz Biotechnology, Heidelberg, Germany); horseradish peroxidase-labeled goat-anti-rabbit $\operatorname{IgG}$ and goat-anti mouse $\operatorname{IgG}(1$ : 2,000, Jackson ImmunoResearch Laboratories, West Grove, PA)].

Immunohistochemistry. The kidneys of anesthetized adult rats and mice were fixed by vascular perfusion with $3 \%$ paraformaldehyde and processed for immunohistochemistry as previously described (34). The kidneys of newborn GR $+/+$ and GR $-/-$ mice were fixed by immersion in $4 \%$ paraformaldehyde for $48 \mathrm{~h}$ at $4{ }^{\circ} \mathrm{C}$ and embedded in paraffin according to routine procedures. Serial cryosections or paraffin sections (4 $\mu \mathrm{m}$ thick each) were incubated with one of the following primary antibodies: [monoclonal mouse anti-rat-MR (rMR1-18) (24), polyclonal rabbit anti-mouse-GR (M-20, sc-1004 Santa Cruz Biotechnology), polyclonal rabbit anti-human-GR (PA1511A; Affinity Bioreagents-Thermoscientific, Rockford, IL), polyclonal rabbit anti-rat Na-K-2Cl cotransporter (NKCC2) antibody (58), polyclonal rabbit anti-rat $\mathrm{Na}-\mathrm{Cl}$ cotransporter (NCC) antibody (35), polyclonal rabbit anti-rat $\beta$-ENaC antibody (58), polyclonal sheep anti-rat $11 \beta$-HSD2 antibody (Chemicon Millipore, Hofheim, Germany), and polyclonal rabbit anti-rat calbindin $\mathrm{D}_{28 \mathrm{~K}}$ (Swant, Bellinzona, Switzerland)]. The binding sites of the primary antibodies were revealed by Cy3-conjugated goat anti-rabbit IgG (Jackson ImmunoResearch Laboratories) and FITC-conjugated goat anti-mouse IgG (Jackson ImmunoResearch Laboratories), respectively. All antibodies dilutions were in PBS-1\% BSA.

Evaluation of immunofluorescence. The sections were studied with a Zeiss fluorescence microscope by three investigators (D. Ackermann, M. Carrel, and J. Loffing), who were blinded to the treatment of the animals. Tubular segments were identified according to standard morphological criteria. TAL, DCT, CNT, and CD were distinguished on the basis of their localization in the cortical labyrinth and in the medullary rays, respectively. Qualitative judgments regarding immunostainings were similar for all investigators.

Statistics. Results are expressed as means \pm SE. The data followed a normal distribution, and the groups were compared using a twosided unpaired $t$-test.

\section{RESULTS}

Localization of $M R$ and GR mRNA along the mouse nephron. We used RT-PCR to detect MR and GR transcripts in microdissected nephron portions from normal mice (Fig. 1).

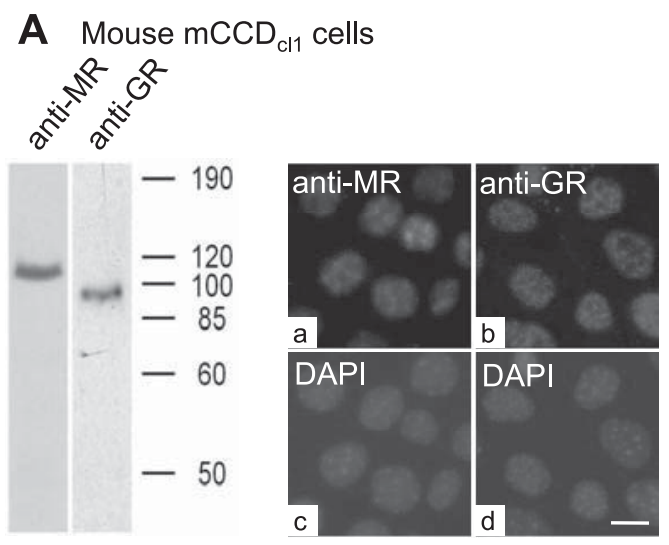

\section{B Mouse kidney}

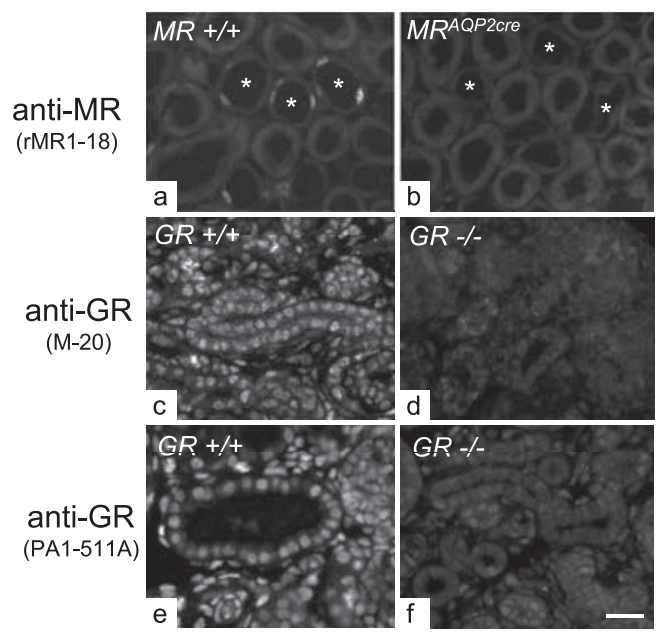

Fig. 2. A: detection of MR and GR in the mouse collecting duct cell line mCCDcl1. The mCCD cells were grown on permeable supports and then processed for either immunoblotting (left) or immunocytochemistry (right) as described in MATERIALS AND METHODS. In immunoblots, MR and GR antibodies (rMR1-18 and M-20, respectively) detect bands of the expected sizes for MR (107 kDa) and GR (94 kDa), respectively. In immunocytochemistry the MR and GR antibodies (rMR1-18 and M-20, respectively) show the expected staining of cell nuclei that were counterstained with the DNA dye 4,6-diamidino-2-phenylindole (DAPI). Scale bar $=\sim 5 \mu \mathrm{m}$. $B$ : detection of MR and GR in kidneys of control mice $(\mathrm{MR}+/+$ and $\mathrm{GR}+/+)$ and mice with either a collecting system-specific deletion of the $\mathrm{MR}$ (MR ${ }^{\mathrm{AQP}}{ }^{\mathrm{A} e}$ ) or constitutive deletion of the GR in all organs. While MR and GR are readily detectable in control mice, MR and GR staining are absent in cells with targeted deletion of MR and GR. Asterisks indicate medullary collecting ducts in $\mathrm{MR}+/+$ and $\mathrm{MR}-/-$ mice. The used antibodies are indicated in brackets. Scale bar $=\sim 20 \mu \mathrm{m}$. 
Messenger RNA for MR was present in all distal tubules, including medullary and cortical TAL, DCT, CNT, and the entire CD, while glomeruli and proximal tubules did not show any detectable MR expression. GR mRNA was found in all microdissected sample preparations (Fig. 1).

Specificity of MR and GR antibodies. To further validate the mRNA data, we studied MR and GR expression at the protein level. We took advantage of already available mouse anti-MR (rMR1-18) (24) and anti-GR antibodies (M-20 and PA1511A). The specificity of the antibodies was confirmed by using, as a positive control, specimens from a highly differentiated mouse collecting duct cell line $\left(\mathrm{mCCD}_{\mathrm{cl} 1}\right)$ with known functional MR and GR expression (19). Kidneys of transgenic mice with a conditional deletion of the MR in the collecting duct (46) and kidneys from mice with a constitutive deletion of the GR in all cell types (6) served as negative controls (Fig. 2). Immunoblotting with cell lysates from the mCCD cells showed that the MR and GR antibodies detect single bands of the expected sizes of native MR and GR, respectively (Fig. $2 A$ ). In immunofluorescent experiments in mCCD cells, MR and GR antibodies showed the expected nuclear localization of the receptors (Fig. 2A). Similarly, MR and GR antibodies showed a clear nuclear staining pattern in renal tubules of kidneys from wild-type mice, which was absent in the corresponding cells of the proper control knockout mouse models (Fig. 2B).

Distribution of $M R$ and GR protein along the rat nephron. Coimmunostainings with MR or GR antibodies and with nephron-specific marker molecules were used to unequivocally localize the receptors along the rat nephron. Consistent with the RT-PCR results, the MR was readily detected in cell nuclei of NKCC2-positive TALs, NCC-positive DCTs, ENaC-positive CNTs and CCD cells, as well as $\mathrm{H}^{+}$-ATPase-positive intercalated cells (Fig. 3). Among the latter, all subtypes including type-A and type-B intercalated cells were MR positive (Fig. 3). The staining pattern and intensities were similar for CNT and CD. However, the MR-related immunostaining was usually more pronounced in the segment-specific cells than in the intercalated cells. In the latter, staining intensity varied, but consistent differences between intercalated cell subtypes were not observed. Proximal tubules were always MR negative. Occasionally, glomeruli revealed very weak nuclear staining that we, however, consider as unspecific as it was observed rarely and RT-PCR experiments did not show any detectable MR-related mRNA in glomeruli. In contrast to the distinct localization of the MR to distal tubules, the GR showed a ubiquitous expression and was found by immunohistochemistry in cell nuclei of cells in glomeruli, proximal tubules, and distal tubules including TALs, DCTs, CNTs, and CDs. In DCT, CNT, and CD, both calbindin $\mathrm{D}_{28 \mathrm{~K}}$-positive principal cells as well as calbindin $\mathrm{D}_{28 \mathrm{~K}}$-negative intercalated cells showed a nuclear localization of the GR (Fig. 4, $A$ and $B$ ). Interestingly, proximal tubules revealed, in addition to the nuclear staining, a small rim of immunofluorescence at the apical cell side. Costainings with phalloidin-FITC, which labels filamentous actin (F-actin), demonstrated that this GRrelated immunostaining localized to the so-called subapical compartment, which lies just below the F-actin-rich brush border (Fig. 4, $\mathrm{C}-\mathrm{H}$ ). Subapical immunostaining was also seen in perfusion-fixed kidneys of adult mice (not shown), but it was not visible in the immersion-fixed kidneys of newborn mice (neither GR $+/+$ nor GR $-/-$ mice) (Fig. 2). Therefore, we cannot finally prove the specificity of the subapical staining, but the fact that two different rabbit anti-GR antibodies directed against different epitopes show the same subapical
Fig. 3. Distribution of MR in the renal cortex of a control rat. Cryostat sections of the kidney coimmunostained with monoclonal antibodies against MR (green) and rabbit polyclonal antibodies against the $\mathrm{Na}-\mathrm{K}-2 \mathrm{Cl}$ cotransporter (NKCC2), the NaCl-cotransporter (NCC), the $\beta$-subunit of the epithelial sodium channel $(\mathrm{ENaC})$, and the $\mathrm{H}^{+}$-ATPase (all shown in red) are shown. A: overview. MR is highly abundant in cell nuclei of NKCC2-positive TAL (T), NKCC2-negative DCT (D), CN, and adjacent $\mathrm{CD}$, but is absent from proximal tubule (P). $B-D$ : higher magnifications confirm that MR is expressed in NCC-positive DCT $(B), \beta$-ENaC-positive segment-specific cells of the $\mathrm{CD}(C)$, and in $\mathrm{H}^{+}$-ATPase-positive intercalated cells of CD $(D)$. Note that MR is seen in intercalated cells with apical (arrows), basolateral (arrowhead), and diffuse $\mathrm{H}^{+}$-ATPase immunostaining (asterisk), indicating that all intercalated cell subtypes are MR positive. Scale bars $=\sim 20 \mu \mathrm{m}$
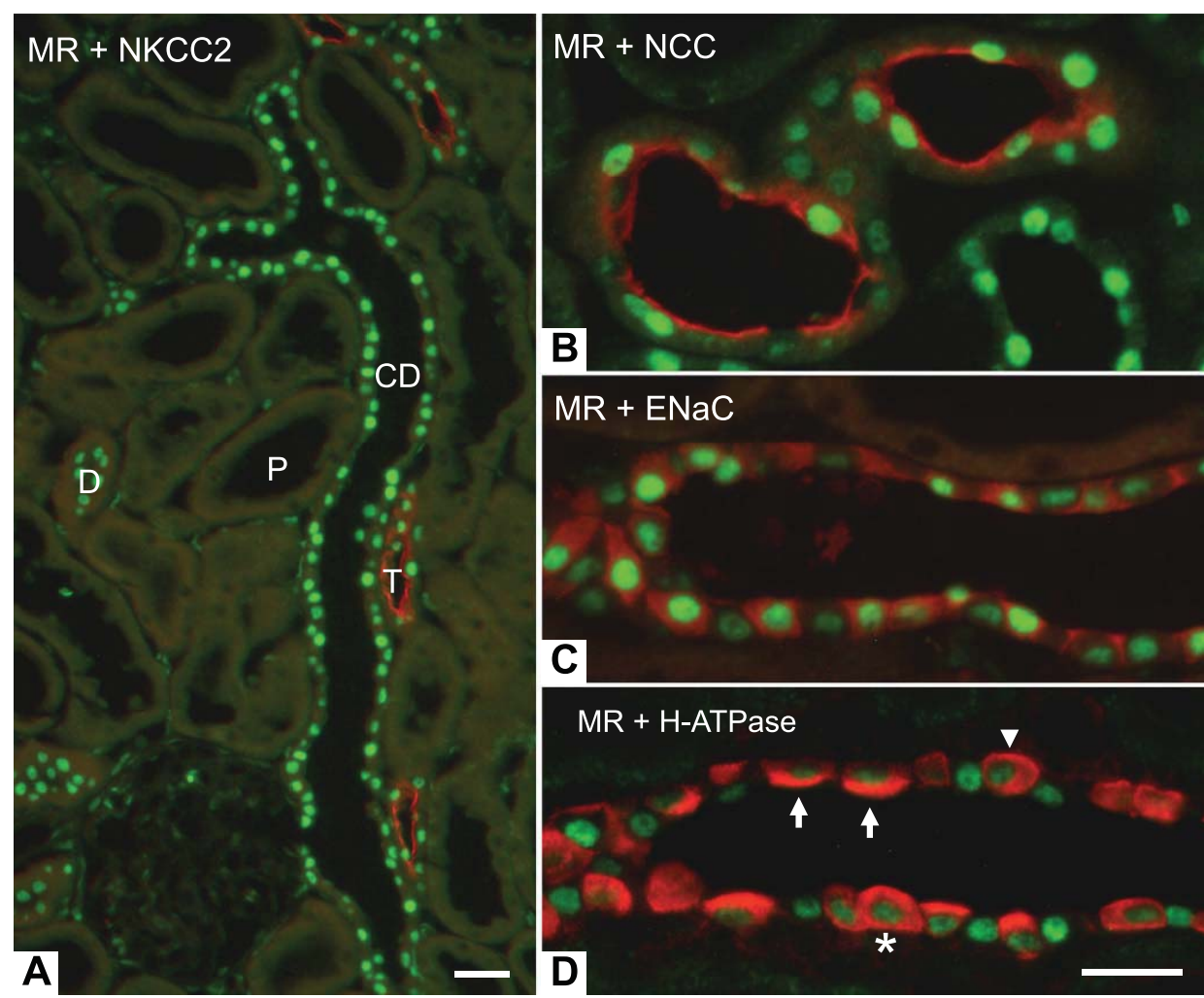

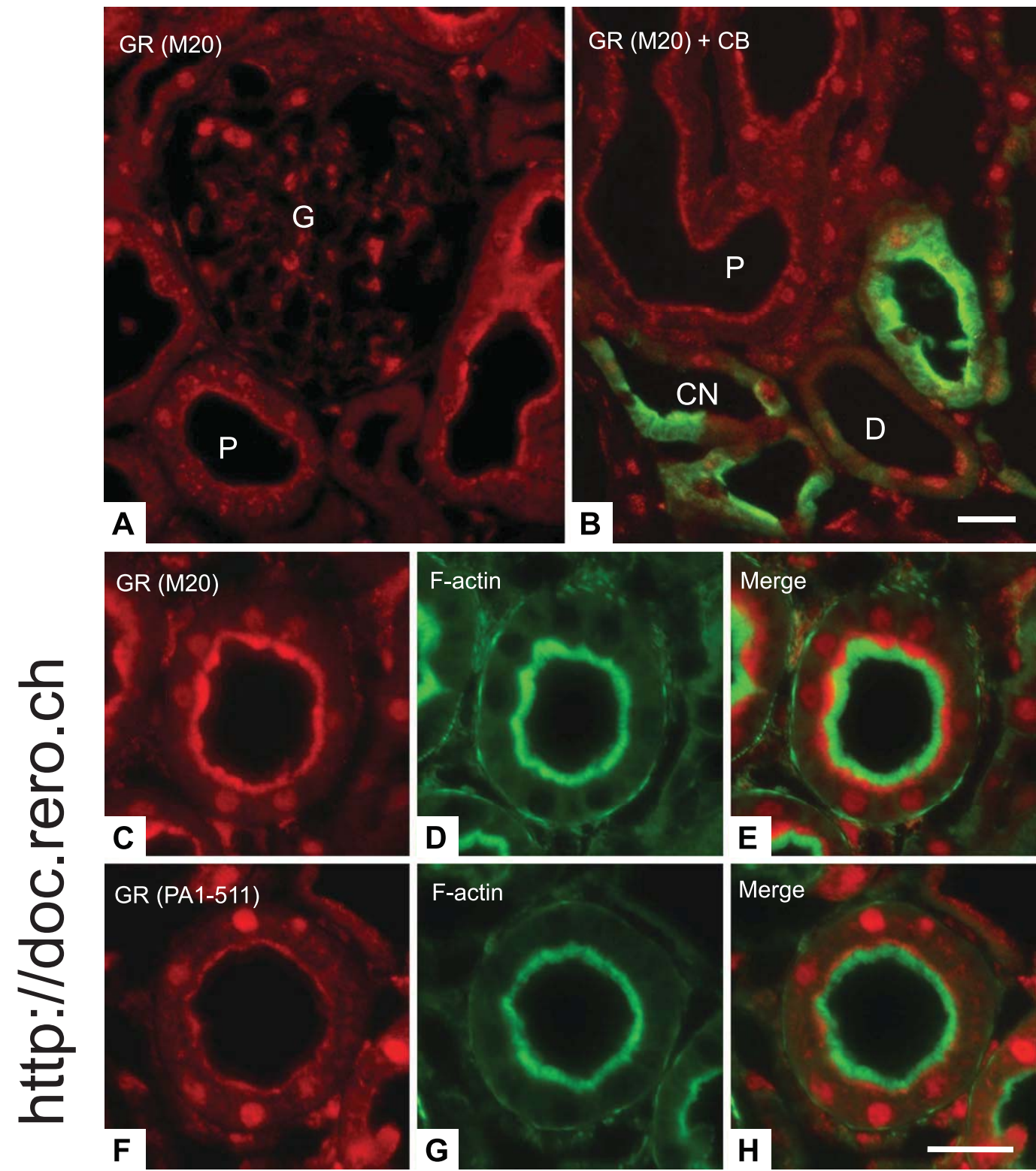

Fig. 4. Distribution of the GR in the renal cortex of a control rat. Cryostat sections were costained with rabbit polyclonal antibodies against GR (red) and mouse monoclonal antibodies against the calcium binding protein calbindin $\mathrm{D}_{28 \mathrm{~K}}(\mathrm{CB})$ or F-actin labeling by phalloidin-FITC (all in green). $A$ and $B$ : renal cortex. GR immunostaining is seen in cell nuclei located in glomeruli (G), proximal tubules (P), in CB-positive DCT (D), and in $\mathrm{CN}$, in which both $\mathrm{CB}$-positive segment-specific $\mathrm{CN}$ cells as well as CB-negative intercalated cells show nuclear GR labeling. In addition to this nuclear labeling, proximal tubules $(\mathrm{P})$ reveal a distinct GR immunostaining at the apical cell side. Higher magnifications $(\mathrm{C}-\mathrm{H})$ resolve that this staining, which is seen with 2 different anti-GR antibodies (i.e., antibodies M20 and PA1-511), is localized just below the F-actin-positive brush border in the so-called subapical compartment. Scale bars $=$ $\sim 20 \mu \mathrm{m}$. staining pattern in rat proximal tubules, which is not seen with any other of the used rabbit antibodies, gives a high degree of confidence in the specificity of the observed staining. Another indication for the specificity of the staining is that the subapical staining is apparently regulated by corticosteroids.

Effect of altered dietary sodium intake. We next tested whether physiologically relevant variations in plasma aldosterone levels may affect the subcellular localization of MR and GR. For that purpose, rats were kept for $1 \mathrm{wk}$ on a high-salt $\left(5 \% \mathrm{Na}^{+}\right)$diet, which suppresses aldosterone secretion from the adrenal glands (25). Surprisingly, a high-salt diet did not remove the MR from the cell nuclei of either NKCC2-postive TAL, NCC-positive DCT, ENaC-positive principal, or ENaCnegative intercalated cells in CNT and CD (Fig. 5). Similarly, the nuclear localization of GR was not affected in cells of proximal tubules, TALs, and DCTs (Fig. 6, $A-D$ ). Only in CNTs and CDs, some of the epithelial cells did not show any nuclear localization of GR any longer. Careful analysis re- vealed that these cells were the ENaC- and calbindin $\mathrm{D}_{28 \mathrm{~K}^{-}}$ positive segment-specific cells, while the $\mathrm{ENaC}$ - and calbindin $\mathrm{D}_{28 \mathrm{~K}}$-negative intercalated cells maintained nuclear GR localization (Fig. 6, $E-G$ ). Double immunostainings further revealed that the segment-specific CNT and CD cells lacking nuclear GR localization are those cells that express high levels

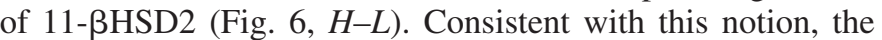
nuclear localization of GR varies along the DCT. In the early DCT (DCT1), where 11- $\beta$ HSD2 expression is low, the nuclear localization of the GR is strong. However, it vanishes progressively along the late DCT (DCT2) with the increasing 11BHSD2 levels and becomes finally almost undetectable in the end portion of the DCT2, similar to the situation in the segment-specific cells of the CNT (Fig. 7, $A-D$ ). Thus the selective lowering of plasma aldosterone concentration by increased dietary sodium intake has no effect on the subcellular localization of MR, but removes the GR from the nuclei of cells expressing high levels of 11- $\beta$ HSD2. 
Fig. 5. Detection of the MR in the renal cortex of a rat kept for 5 days on a high-NaCl $\left(5 \% \mathrm{Na}^{+}\right)$diet. Cryostat sections costained with mouse monoclonal antibodies against MR (green) and rabbit polyclonal antibodies against either $\mathrm{NKCC} 2(A), \mathrm{NCC}(B)$, or $\beta$-ENaC $(C$; all in red). MR is present in the cell nuclei of NKCC2-positive TAL (T) cells, NCC-positive DCT (D) cells, and ENaCpositive segment-specific cells and $\mathrm{ENaC}-$ negative intercalated cells in $\mathrm{CN}$. Scale bar $=$ $\sim 20 \mu \mathrm{m}$.
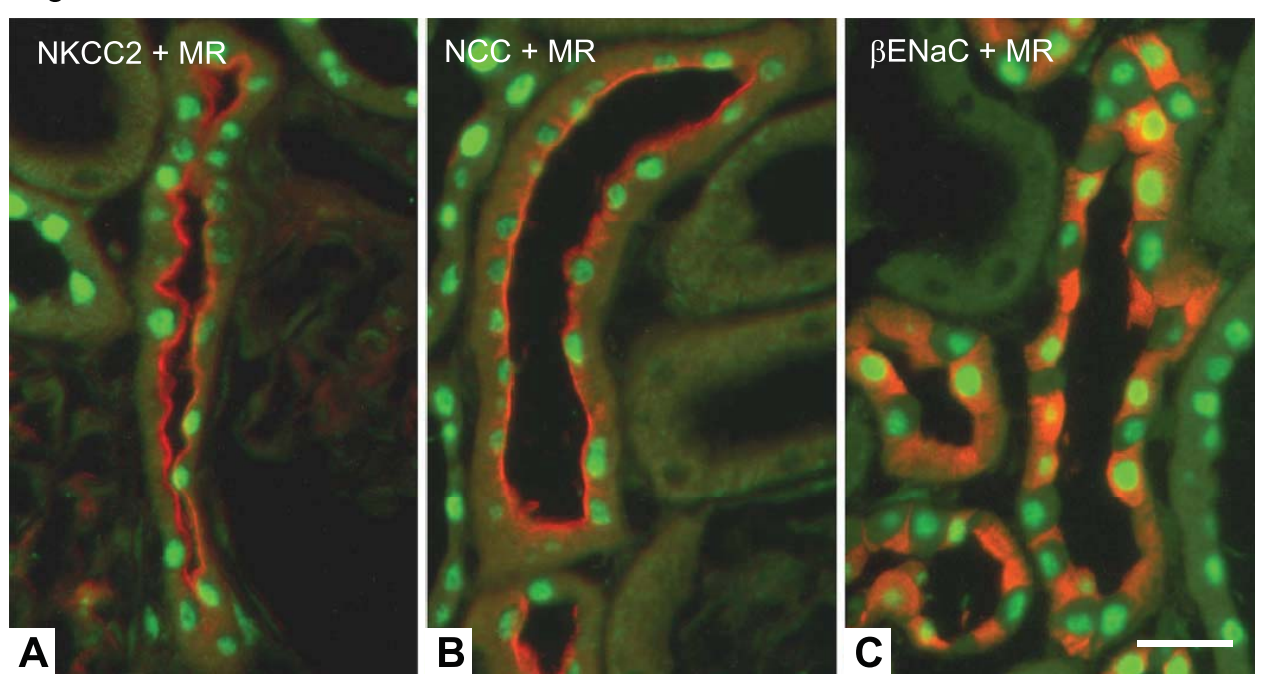

Effect of adrenalectomy and aldosterone replacement. We next tested whether complete deprivation of any endogenous adrenal aldosterone and corticosterone production might affect the nuclear localization of MR and GR. For that purpose, rats were adrenalectomized (ADX). As expected, bilateral ADX completely removed MR and GR from the cell nuclei of all renal cell types (Fig. 8, $A$ and $C$ ). Interestingly, also the intensity of the subapical GR immunostaining in proximal tubules was decreased. Continuous infusion of aldosterone (1 $\mu \mathrm{g} \cdot \mathrm{kg}$ body $\mathrm{wt}^{-1} \cdot \mathrm{h}^{-1}$ ) for $4 \mathrm{~h}$ rapidly relocated MR and GR to the cell nuclei, which occurred virtually in all tubular epithelial cells with known MR and GR expression (Fig. 7, $B$ and $D$ ). Similarly, the aldosterone infusion increased the subapical GR immunostaining in proximal tubules (Fig. 8D). The aldosterone-induced nuclear translocation was paralleled by a lower urinary $\mathrm{Na}^{+} / \mathrm{K}^{+}$excretion in aldosterone-treated than in vehicle-treated rats (Fig. 8E), confirming the physiological significance of the altered subcellular localization of the receptors.

Effect of low- and high-dose corticosterone treatment on $A D X$ rats. In pilot experiments, we used the same experimental protocol as above and infused corticosterone at day 2 after ADX at concentrations ranging from 1 to $100 \mu \mathrm{g} \cdot \mathrm{kg}$ body $\mathrm{wt}^{-1} \cdot \mathrm{h}^{-1}$. To our surprise, even the subphysiological replacement dose of $1 \mu \mathrm{g} \cdot \mathrm{kg}$ body $\mathrm{wt}^{-1} \cdot \mathrm{h}^{-1}$ caused a pronounced nuclear localization of GR and MR in all GR- and MRexpressing cell types, including the $11 \beta$-HSD2-positive CNT and CD cells (data not shown). We speculated that the 2-day gap between ADX and corticosterone replacement may have lowered the $11 \beta$-HSD2 activity due to the absence of its endogenous substrate. In fact, previous observation in A6 cells and mCCD cells in vitro supported the idea that maintenance of high activity of $11 \beta$-HSD2 depends on the continuous presence of corticosteroids $(19,20)$. Accordingly, we changed our experimental protocol and substituted corticosterone immediately after ADX. Interestingly, only high-dose corticosterone replacement $\left(100 \mu \mathrm{g} \cdot \mathrm{kg}\right.$ body $\left.\mathrm{wt}^{-1} \cdot \mathrm{h}^{-1}\right)$ caused nuclear localization of all MR and GR in all epithelial cell types expressing these receptors. Low-dose corticosterone replacement $(1 \mu \mathrm{g} \cdot \mathrm{kg}$ body $\mathrm{wt}^{-1} \cdot \mathrm{h}^{-1}$ ) induced a nuclear localization of the MR in ENaC-negative distal tubules as well in the $\mathrm{ENaC}$-positive
ASDN, but located the GR to the nucleus only in proximal tubules, TALs, DCTs, and intercalated cells, but not in the classical ASDN cells with strong 11 $\beta$-HSD2 expression (Fig. 9, $A-D)$. Consistent with the differential regulation of the GR in the 11ß-HSD2-positive ASDN cells, only high-dose, but not lowdose corticosterone treatment lowered the urinary $\mathrm{Na}^{+} / \mathrm{K}^{+}$excretion compared with vehicle administration (Fig. 9E).

\section{DISCUSSION}

Previous studies localized the MR and GR along the mammalian nephron using RNAase protection and ligand-binding assays on microdissected nephron portions (7, 10-12, 15, 33, 53) and autoradiography, in situ hybridization, and immunohistochemistry on kidney sections $(4,13,32,37,55)$. Together with data on the localization of the $11 \beta-H S D 2$ (reviewed in Refs. 4, 14, and 56), the data helped to define the ASDN. However, several questions regarding the precise cellular localization of MR and GR in non-ASDN cells and about the regulation of the subcellular localization of these receptors by corticosteroids in the kidney in vivo remained open. In the present study, we used detailed immunohistochemistry to provide a comprehensive analysis of the localization and corticosteroid-dependent regulation of $\mathrm{MR}$ and GR along the rat nephron. Our study confirms the prominent expression of MR, GR, and 11ß-HSD2 in the ASDN. Moreover, we show for the first time convincingly the localization of MR and GR in all types of intercalated cells and establish the subcellular distribution pattern of MR and GR in ASDN and several non-ASDN cell types. Moreover, the present data reveal a distinct pattern of differential regulation of the subcellular localization of MR and GR in the various renal epithelial cell types, which allows inferring on sites and mechanisms of the complex activity of these receptors along the renal tubule.

Cellular localization of MR. The prominent localization of the $\mathrm{MR}$ in ENaC-positive ASDN cells is not surprising. It agrees with previous data and supports the present concept of aldosterone action (56). However, our study reveals MR expression also in the TALs and in intercalated cells, which express no or very little $11 \beta-H S D 2$ and which are considered 

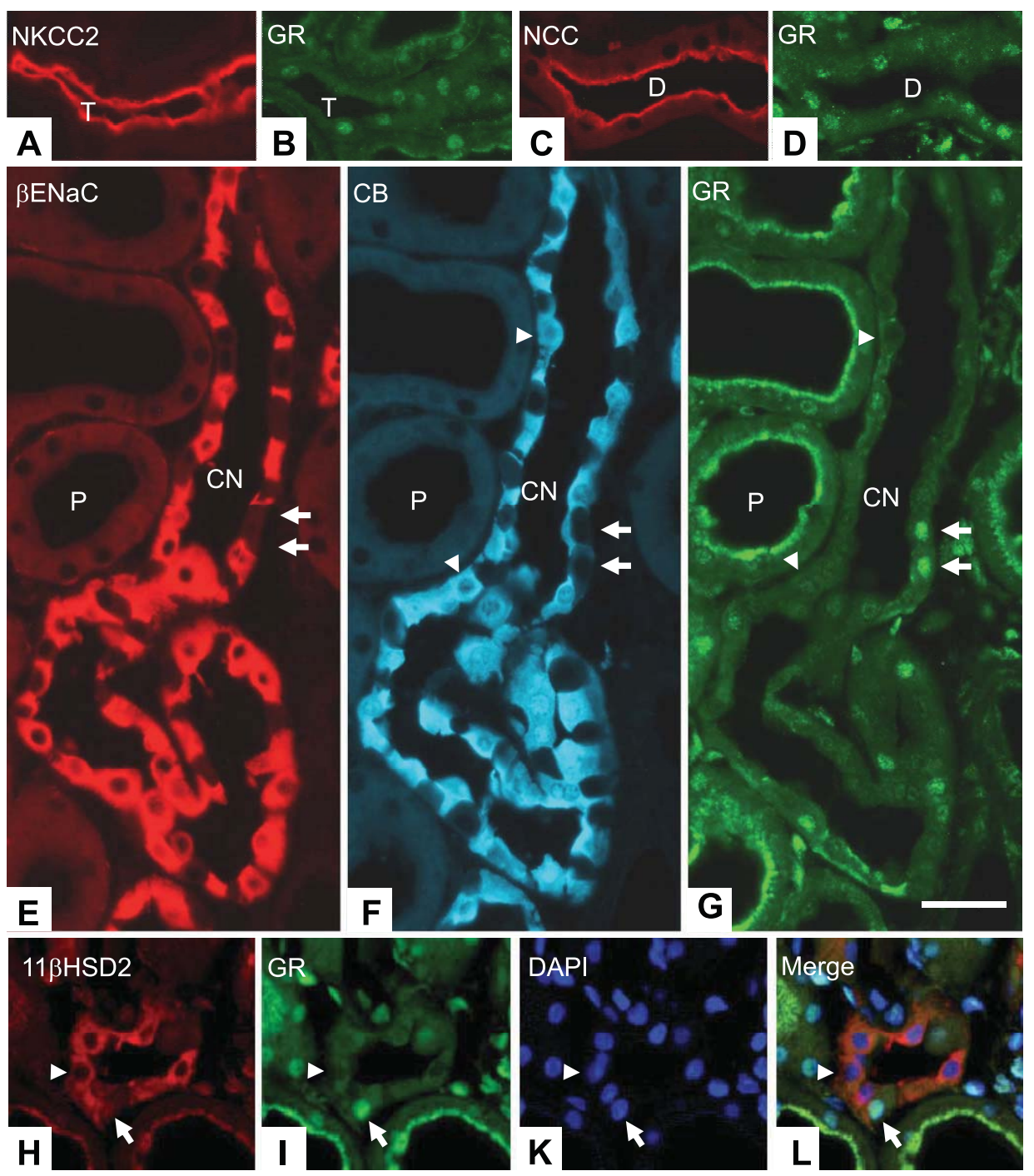

not to belong to the classic aldosterone target cells. Strong MR mRNA and protein expression in the TAL has been previously reported $(10,11,13,32,37,55)$, but other RT-PCR (53), immunohistochemical (4), and hormone binding data (39) suggested a rather low abundance of MR protein at this site compared with the classic ASDN. Now, we found a surprisingly strong immunostaining for the MR in the TAL, which was only slightly lower than that seen in the classic ASDN cells. The strong MR expression in the TAL is consistent with previous reports describing a profound stimulatory action of aldosterone on TAL sodium transport $(51,61)$ but contrasts with other studies that did not reveal any effect of aldosterone on the expression and activity of the Na-K-ATPase and the potassium transport in the TAL of ADX rabbits and rats, respectively $(9,21,54)$. Thus the physiological role of aldosterone in the TAL remains obscure. Our observation that the subcellular localization of MR is only regulated by aldosterone when glucocorticoids are absent (i.e., in ADX animals), indicates that physiological variations of aldosterone in intact animals are not sufficient to elicit aldosterone-specific MRmediated transcriptional effects in the TAL.

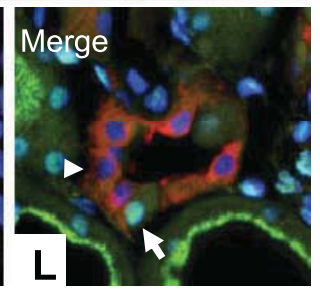

Fig. 6. Detection of the GR in the renal cortex of rats kept for 5 days on a high- $\mathrm{NaCl}(5 \%$ $\mathrm{Na}^{+}$) diet. Immunostainings for GR (green) and segment- and cell-specific marker molecules (red or blue) on pairs of consecutive cryosections are shown. $A-D: 2$ pairs of consecutive cryosections show that GR is present in cell nuclei of NKCC2-positive-positive TAL (T) cells $(A$ and $B)$ and NCC-positive DCT cells $(C$ and $D) . E$ and $F: 1$ pair of consecutive cryosections stained with either a rabbit-polyclonal antibody against $\beta-\mathrm{ENaC}(E)$ or costained with mouse monoclonal antibodies against $\mathrm{CB}$ $(F)$ and rabbit polyclonal antibodies against GR $(G)$. GR is seen in the cell nuclei of proximal tubules $(\mathrm{P})$ and in $\beta$-ENaC- and $\mathrm{CB}$-negative intercalated cells (arrows) of CN. $\beta-\mathrm{ENaC}$ - and CB-positive $\mathrm{CN}$ cells (arrowheads) do not show any nuclear GR labeling. $H-L$ : cryostat section costained with sheep polyclonal antibodies against $11 \beta$-hydroxysteroid dehydrogenase type $2(11 \beta-H S D 2 ; H)$, rabbit polyclonal antibodies against GR (M-20; $I)$, and the DNA dye DAPI $(K)$ shown in separate red, green and blue colors $(H-K)$ or in a merged image $(L)$. The GR is seen in the cell nuclei of only those cells that do not express $11 \beta$-HSD2. Scale bar $=$ $\sim 20 \mu \mathrm{m}$.
Another surprising observation in our study is the prominent localization of the MR in all types of intercalated cells. Although ex vivo studies on immunoisolated type-B intercalated cells suggested the expression of MR in at least this subtype of intercalated cells (41), previous immunohistochemical studies consistently failed to detect any MR localization within intercalated cells in the kidney $(4,13,37)$. Aldosterone is known to stimulate renal proton excretion (52), but this effect is thought to be indirect and related to activation of ENaC-dependent sodium transport in principal cells, which increases the electrochemical driving force for proton secretion by intercalated cells. Given the low expression level of $11 \beta$-HSD2 and the pattern of MR and GR regulation within intercalated cells, it is unlikely that aldosterone has significant direct genomic effects on intercalated cells, at least in the physiological context of severalfold higher plasma levels of corticosterone than aldosterone. However, MR expression in intercalated cells may become relevant in patients with pharmacological (e.g., by spironolactone) or genetic (i.e., pseudohypoaldosteronism type 1) MR inactivation. Under these conditions, the loss of MR function in intercalated cells may contribute to the development of metabolic acidosis that 
Fig. 7. Detection of the GR along the DCT of a rat kept for 5 days on a high- $\mathrm{NaCl}\left(5 \% \mathrm{Na}^{+}\right)$ diet. Immunostainings with rabbit polyclonal antibodies against NCC $(A)$, sheep polyclonal antibodies against $11 \beta$-HSD2 $(B)$, mouse monoclonal antibodies against $\mathrm{CB}(C)$, and rabbit polyconal antibodies against GR (M$20 ; D)$ on either consecutive $(A, B, C / D)$ or the same $(C$ and $D)$ cryosections are shown. The DCT begins at the end of the TAL (T) and is characterized along its entire length by the expression of the NCC. The early DCT (1) and the late DCT (2) can be distinguished based on the different expression levels of $11 \beta$-HSD2 and CB, which are low in early DCT (1) and are high in late DCT (2). The GR is highly abundant in the cell nuclei of proximal tubules (P), TAL (T), and early DCT (1), but vanishes along the late DCT (2) in parallel with the increasing 11ß-HSD2 levels. In the end portion of the late DCT $\left(2^{*}\right)$, nuclear GR localization is barely visible, which is similar to the $\mathrm{CN}$. In the latter, only the CB-negative intercalated cells (arrows) show bright nuclear immunostaining for the GR. Scale bar $=\sim 20 \mu \mathrm{m}$.
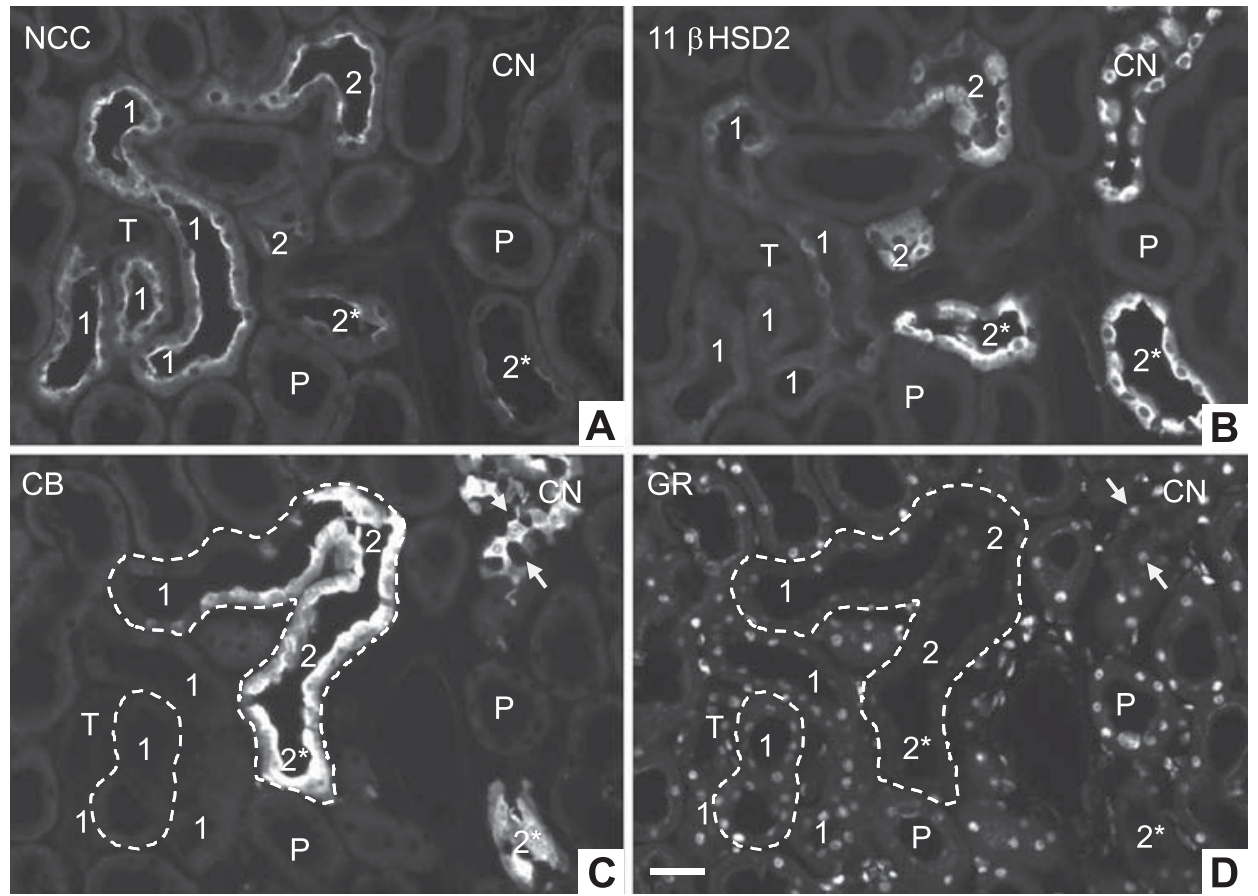

is frequently seen in these patients $(23,44)$. Whether the MR may also contribute to the rapid nongenomic effects of aldosterone in intercalated cells remains elusive (60). Thus additional studies are warranted to address the yet unclear physiological relevance of the MR in the TAL and in intercalated cells. The recent generation of a transgenic mouse model with floxed alleles for the MR may allow further addressing the cell type-specific roles of the MR (46).

Cellular localization of GR. The GR is thought to be expressed in virtually all cell types of the mammalian organism. Hence, it was surprising that immunohistochemical studies failed to detect the GR in proximal tubules (13), although mRNA analysis $(10,53)$ and autoradiographic binding studies $(15,33)$ clearly indicated that the GR is present in proximal tubules like in all other renal epithelial cells. To explain these findings, Farman and coworkers (13) speculated that the proximal tubule may express a GR isoform that their monoclonal mouse antibody may not bind to because the recognized epitope is either lacking or masked by interacting proteins, for example. In the present study, we used two rabbit polyclonal antibodies directed against different epitopes and could now unequivocally demonstrate that the GR is abundant at the protein level in all renal cells types, including proximal tubular cells. Interestingly, in proximal tubules the GR accumulated not only in cell nuclei, but also in the region of the subapical compartment (SAC). The SAC is formed by a network of tubulovesicular structures involved in endocytotic and exocytotic trafficking of membrane vesicles and membrane proteins $(28,29)$. Moreover, the SAC participates to receptor-mediated endocytosis of plasma proteins, which have been filtered in renal glomeruli (5). It is unlikely that the GR is an endo- or exocytosed protein, but the accumulation of the GR within the SAC may position the receptor perfectly well to rapidly bind ligands that enter the cells from the tubular lumen. This luminal ligand uptake may not only concern corticosteroids that were freely filtered at the glomeruli but also those that were filtered bound to plasma proteins. In fact, there is increasing evidence that steroid hormones may enter certain cell types not only by free diffusion but also by receptor-mediated endocytosis of their carrier proteins (59). Notably, circulating corticosteroids are bound $>90 \%$ to corticosteroid-binding globulin (CBG), which has a molecular mass of $55 \mathrm{kDa}(27)$, which is just below the $60 \mathrm{kDa}$ cut-off of the glomerular filter. There is experimental evidence for glomerular filtration of plasma protein-bound corticosteroids (17), and binding of CBG to renal cell membranes (50) and localization of CBG in the subapical region of proximal tubule cells have been demonstrated (49). Independent of the underlying uptake mechanism and the subsequent fate of the corticosteroid hormones, the strong dependence of the subapical localization of the GR on the presence of circulating corticosteroids (fig. 7) suggests that the GR is involved in the reuptake of corticosteroids filtered at the glomeruli, which may impact on the bioavailablity of the hormones locally at the level of the proximal tubule, but also along the downstream nephron portions.

Corticosteroid-dependent regulation of MR and GR nuclear localization. Our data show that corticosteroids control the nuclear localization of MR and GR not only in cell systems in vitro, as previously reported $(16,43)$, but also in the kidney in vivo. By and large, the present findings support the classic concepts of MR and GR regulation by corticosteroid hormones. However, with respect to the ASDN, our data indicate that the current textbook dogma that mineralocorticoids act mainly via the MR, which is protected from activation by glucocorticoids due to the action of 11ß-HSD2, may need additional refinement. Using a set of experiments in intact rats on different sodium intakes and in ADX rats treated with different corticosterone replacement doses, we provide evi- 


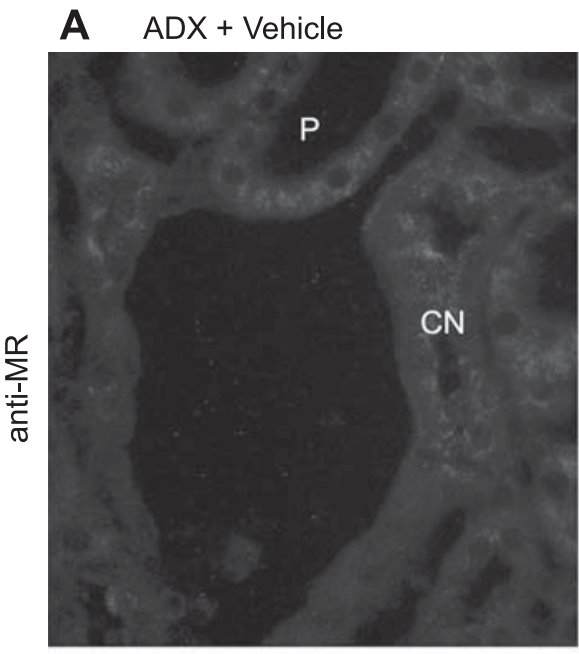

C
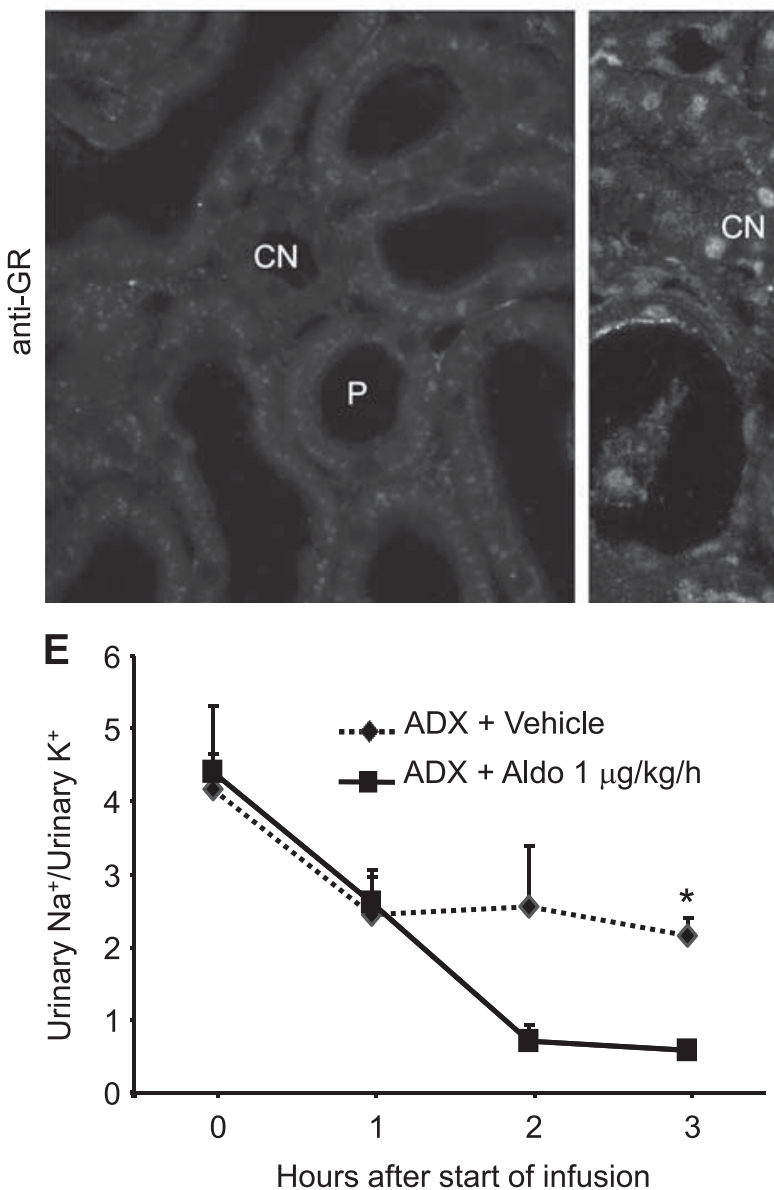

dence that in the kidney in vivo it is not the MR, but mainly the GR, the subcellular localization of which is controlled by physiological variations in plasma aldosterone levels and that it is mainly the GR which is protected by the $11 \beta-H S D 2$ from circulating corticosteroids. This conclusion may surprise at first glance, but it is fully compatible with the current knowledge about the physiological plasma concentrations of aldosterone and corticosterone, the $K_{\mathrm{d}}$ values of MR and GR, and the presumed activity of $11 \beta-H S D 2$. Under standard conditions,

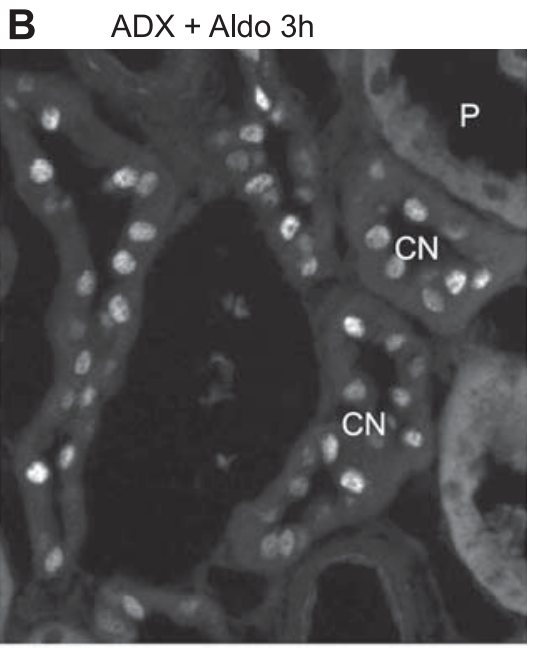

D

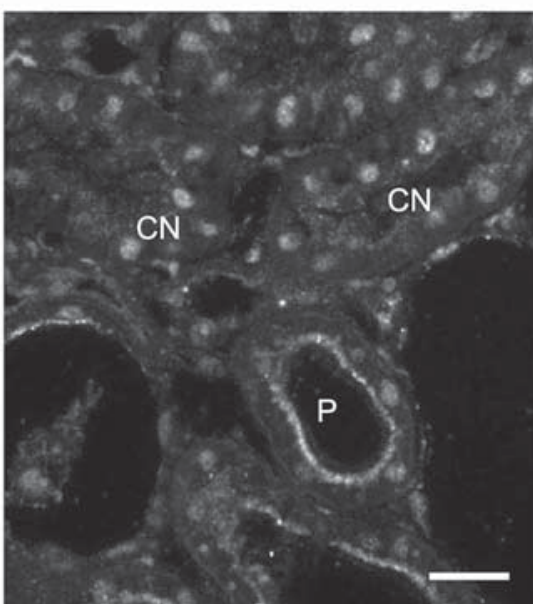

Fig. 8. Effect of aldosterone infusion on subcellular localization of MR and GR $(A-D)$ and urinary $\mathrm{Na}^{+}$and $\mathrm{K}^{+}$excretion $(E)$ in adrenalectomized (ADX) rats. Immmunostainings with mouse monoclonal antibodies against MR ( $A$ and $B$ ) and rabbit polyclonal antibodies (M-20) against GR ( $C$ and $D$ ) in the renal cortex of ADX rats that received either vehicle only (left) or an infusion of aldosterone $\left(1 \mu \mathrm{g} \cdot \mathrm{kg}\right.$ body $\mathrm{wt}^{-1} \cdot \mathrm{h}^{-1} ;$ right $) 3 \mathrm{~h}$ before fixation of the kidneys as described in MATERIALS AND METHODS are shown. In vehicle-treated ADX rats, MR and GR are absent from the cell nuclei of all renal epithelial cells including those of proximal tubules (P) and $\mathrm{CN}$. Three hours after aldosterone infusion, MR and GR are located in the cell nuclei. Three hours after aldosterone infusion was started, the ratio of urinary $\mathrm{Na}^{+}$ to urinary $\mathrm{K}^{+}$is significantly lower in aldosterone- than in vehicle-treated rats (mean $\pm \mathrm{SE}, n=3$ /group, $* P<$ 0.05 vs. vehicle). Scale bar $=\sim 20 \mu \mathrm{m}$. rats have plasma concentrations of aldosterone and corticosterone in the range of $\sim 1$ and 1,000 $\mathrm{nM}$, respectively (25), whereby only part of the corticosterone is thought to be active since most is bound to CBG. The MR and GR bind both hormones with more or less similar affinities, but with clearly different $K_{\mathrm{d}}$ values [i.e., $\mathrm{MR}\left(K_{\mathrm{d}} 0.5-3 \mathrm{nM}\right)$ and $\mathrm{GR}\left(K_{\mathrm{d}} 20-65\right.$ $\mathrm{nM})$ ] (1). As pointed out by Funder (18), it is well possible that $11 \beta$-HSD2 does not achieve a $100 \%$ inactivation of corticosterone before it can bind to the MR and GR. Even if $99 \%$ 
Fig. 9. Effect of low-dose $\left(1 \mu \mathrm{g} \cdot \mathrm{kg}\right.$ body wt $\left.\mathrm{w}^{-1} \cdot \mathrm{h}^{-1}\right)$ and high-dose $\left(100 \mu \mathrm{g} \cdot \mathrm{kg}\right.$ body $\left.\mathrm{wt}^{-1} \cdot \mathrm{h}^{-1}\right)$ corticosterone replacement on subcellular localization of MR and GR $(A-D)$ and urinary $\mathrm{Na}^{+}$and $\mathrm{K}^{+}$excretion $(E)$ in ADX rats. Coimmunostainings with mouse monoclonal antibodies against MR are shown in green, rabbit polyclonal antibodies against $\beta$-ENaC in red $(A$ and $B$ ), and coimmunostainings with rabbit polyclonal antibodies (M-20) against GR are shown in green and sheep polyclonal antibodies against $11 \beta$-HSD2 in red $(C$ and $D)$. In ADX rats with low and high corticosterone replacement, MR is located in the cell nuclei of both ENaC-positive $\mathrm{CN}$ and ENaC-negative intercalated cells $(A$ and $B)$. Low-dose corticosterone replacement results in nuclear localization of the GR in proximal tubule (P), DCT (D), and intercalated cells (arrows), which express no or only weak $11 \beta$-HSD2, but not in $\mathrm{CN}$ cells with strong $11 \beta-\mathrm{HSD} 2$ immunostaining (asterisk in $C$ ). Only when corticosterone is replaced at high doses, segment-specific $\mathrm{CN}$ cells with high $11 \beta$ HSD2 expression also show nuclear localization of the GR (asterisk in $D$ ). E: urinary $\mathrm{Na}^{+} /$urinary $\mathrm{K}^{+}$excretion in ADX rats that received by osmotic minipumps either vehicle, low-dose corticosterone $(1 \mu \mathrm{g} \cdot \mathrm{kg}$ body $\left.\mathrm{wt}^{-1} \cdot \mathrm{h}^{-1}\right)$, or high-dose corticosterone $(100 \mu \mathrm{g} \cdot \mathrm{kg}$ body $\mathrm{wt}^{-1} \cdot \mathrm{h}^{-1}$ ) replacement for $48 \mathrm{~h}$ post-ADX. Urine samples were collected in metabolic cages during the last $24 \mathrm{~h}$ of the experiment as described in MATERIALS AND METHODS (means \pm SE, $n=3$ /group, $* P<0.05$ vs. vehicle). Scale bar $=\sim 20 \mu \mathrm{m}$.
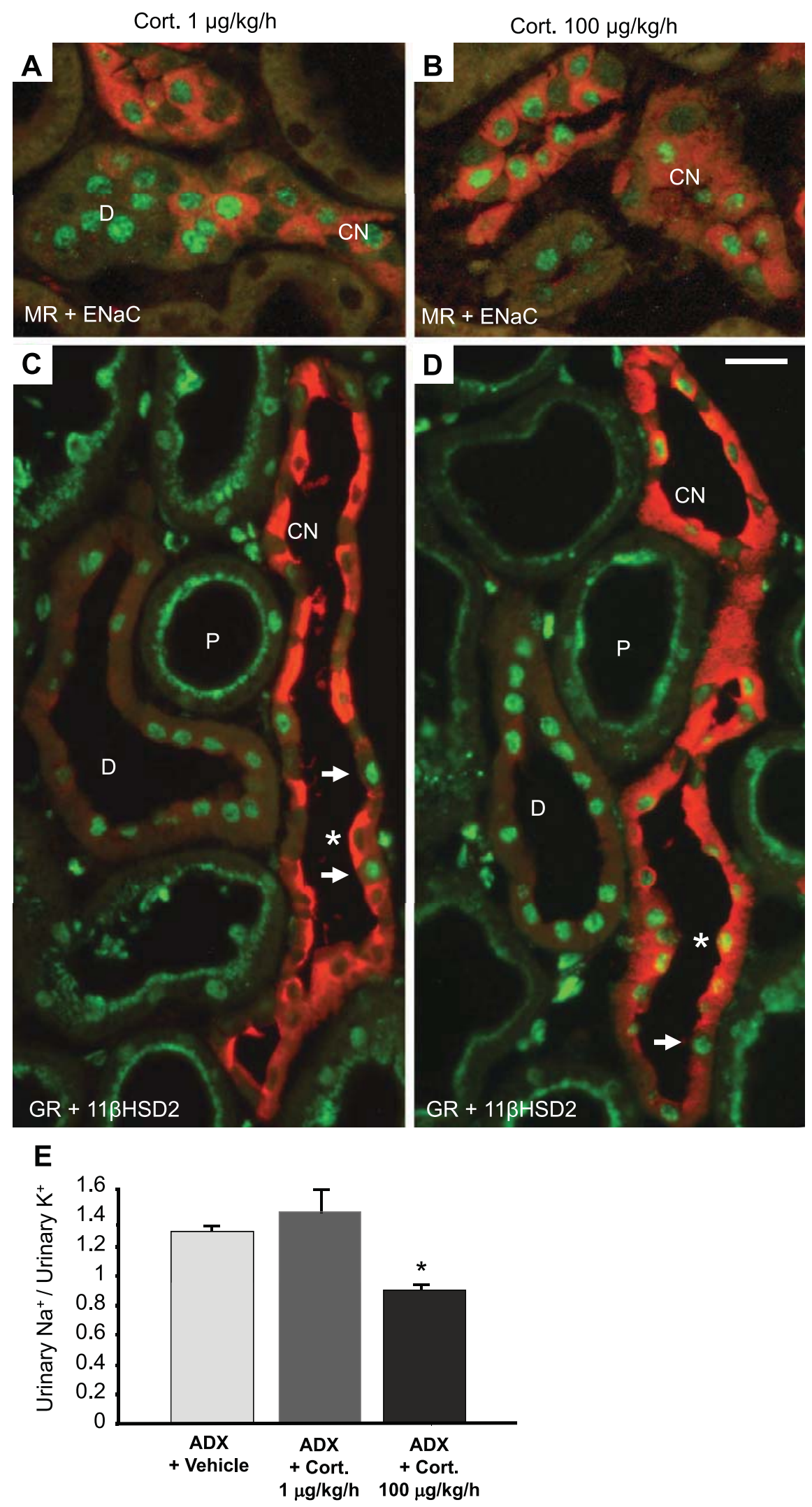

efficiency is achieved, the remaining intracellular corticosterone concentrations in ASDN cells are likely still high enough to bind to and activate most of the MR, but only a small portion aldosterone. Of course, immunofluorescence is not sensitive enough to exclude a further increase in the nuclear localization of MR with increasing plasma aldosterone levels. Moreover, it of the GR and hence leave it available for activation by 
binding of MR to hormone-responsive elements of target genes independently of effects on subcellular localization. In this context, the differential subcellular localization of MR and GR in ASDN cells may even provide an important means by which mineralocorticoid specificity is conferred to the MR. The preferential nuclear localization of the MR under physiological conditions (i.e., with intact adrenal glands) would require that corticosterone diffuses through the cell before it can bind to the MR. This may increase the chance that the $11 \beta-H S D 2$ can fully inactivate corticosterone before it reaches the nucleus. Thus nuclear MR may respond nicely to physiological variations in aldosterone while the GR is shuffling back and forth, linked to altered hormone levels. Mineralocorticoid selectivity might be conferred to the MR also independently of 11 $\beta$-HSD2 by a functional preference of the receptor for aldosterone, as indicated by findings in cell culture assays (38) and in vivo experiments (26).

Role of MR and GR in aldosterone action. The coexpression and differential regulation of MR and GR in ASDN cells raise the apparent question of the role of both receptors and whether both receptors are required for the physiological response to aldosterone. Geering and coworkers (22) were the first to suggest that the occupancy of both receptors is necessary to achieve a full biological response. Although there is evidence for some functional compensation of the GR in MR $-/-$ mice (48), both receptors appear to be important for the control of sodium transport in the ASDN, as indicated by recent findings in mouse models with targeted inactivation of the MR in the renal collecting system (46), overexpression of the GR in the collecting duct (42), or with pharmacological inhibition of either the MR or the GR in ACTH-induced Cushing's syndrome (2). Based on recent experiments in a mouse collecting duct cell line, Gaeggeler and coworkers (19) came up with the idea that the exclusive occupancy of MR provides a limited increase in sodium transport which is adequate for (circadian) maintenance requirements under low plasma aldosterone levels, while occupancy of both receptors would lead to the maximal response needed for maximum sodium retention under severe salt restriction and/or stress. This model, derived from in vitro studies, would be fully compatible with our in vivo findings on the regulation of the subcellular localization of MR and GR along the nephron. Differential dimerization of MR and GR may contribute to a graded response of the ASDN to altered plasma aldosterone levels (47). In fact, dimerization of steroid receptors is required for binding of the ligand-bound receptor complexes to hormone-response elements and activation of gene transcription. The MR and GR can either homodimerize (MR-MR) or heterodimerize (MR-GR). Experiments in which variable proportions of each receptor cDNA were transfected to test their efficiency on a reporter gene revealed that transactivation activity was dependent on the nature of the dimer likely formed (14). In some cases, transcription synergy was evidenced on MR and GR cotransfection, whereas, in other cases, it was shown that MR inhibits GR transcriptional activity. In addition, heterodimers might be formed with only one receptor entity in a liganded state, increasing the diversity of steroid hormone effects (14). Thus a differential regulation of receptor translocation to the cell nucleus would allow for a differential regulation of receptor homo- and/or heterodimerization, which could contribute to the complexity of corticosteroid hormone action in the kidney.
In conclusion, our study provides a detailed analysis of the cellular and subcellular localization of the MR and GR along the nephron and supports the concept that ligand-induced nuclear translocation of MR and GR are important components of $\mathrm{MR}$ and GR regulation in the kidney. In the ASDN, $11 \beta$-HSD2 protects mainly the GR from binding of corticosterone and leaves it available for activation and nuclear redistribution in response to increased plasma aldosterone levels. Differential regulation of MR and GR may alter the level of heterodimerization of the receptors and hence may contribute to the complexity of the corticosteroid effects on ASDN function.

\section{ACKNOWLEDGMENTS}

We gratefully acknowledge the advice of J.-D. Horisberger for the experimental design of the aldosterone and corticosterone infusion experiments in ADX rats. We thank John A. Cidlowski for a suggestion to include also the GR antibody PA1-511A (Affinity Bioreagents/Thermoscientific) in our experiments. We thank Felix J. Frey for helpful comments on the manuscript and Gunther Schütz for giving access to kidneys from GR-deficient mice.

\section{GRANTS}

The study was supported by grants from the Swiss National Science Foundation 310000-122243/1 (to J. Loffing), SPUM: FN 33CM30-124087 (to D. Ackermann), and the Novartis Foundation (to J. Loffing).

\section{DISCLOSURES}

No conflicts of interest, financial or otherwise, are declared by the authors.

\section{REFERENCES}

1. Arriza JL, Weinberger C, Cerelli G, Glaser TM, Handelin BL, Housman DE, Evans RM. Cloning of human mineralocorticoid receptor complementary DNA: structural and functional kinship with the glucocorticoid receptor. Science 237: 268-275, 1987.

2. Bailey MA, Mullins JJ, Kenyon CJ. Mineralocorticoid and glucocorticoid receptors stimulate epithelial sodium channel activity in a mouse model of Cushing syndrome. Hypertension 54: 890-896, 2009.

3. Berger S, Bleich M, Schmid W, Cole TJ, Peters J, Watanabe H, Kriz W, Warth R, Greger R, Schutz G. Mineralocorticoid receptor knockout mice: pathophysiology of $\mathrm{Na}+$ metabolism. Proc Natl Acad Sci USA 95: 9424-9429, 1998.

4. Bostanjoglo M, Reeves WB, Reilly RF, Velazquez H, Robertson N, Litwack G, Morsing P, Dorup J, Bachmann S, Ellison DH. 11Betahydroxysteroid dehydrogenase, mineralocorticoid receptor, and thiazidesensitive $\mathrm{Na}-\mathrm{Cl}$ cotransporter expression by distal tubules. J Am Soc Nephrol 9: 1347-1358, 1998.

5. Christensen EI, Verroust PJ, Nielsen R. Receptor-mediated endocytosis in renal proximal tubule. Pflügers Arch 458: 1039-1048, 2009.

6. Cole TJ, Blendy JA, Monaghan AP, Krieglstein K, Schmid W, Aguzzi A, Fantuzzi G, Hummler E, Unsicker K, Schutz G. Targeted disruption of the glucocorticoid receptor gene blocks adrenergic chromaffin cell development and severely retards lung maturation. Genes Dev 9: $1608-$ $1621,1995$.

7. Doucet A, Katz AI. Mineralcorticoid receptors along the nephron: $\left[{ }^{3} \mathrm{H}\right] \mathrm{al}-$ dosterone binding in rabbit tubules. Am J Physiol Renal Fluid Electrolyte Physiol 241: F605-F611, 1981.

8. Ehlers S, Smith KA. Differentiation of T cell lymphokine gene expression: the in vitro acquisition of T cell memory. J Exp Med 173: 25-36, 1991.

9. El Mernissi G, Doucet A. Short-term effects of aldosterone and dexamethasone on Na-K-ATPase along the rabbit nephron. Pflügers Arch 399: 147-151, 1983.

10. Escoubet B, Coureau C, Blot-Chabaud M, Bonvalet JP, Farman N. Corticosteroid receptor mRNA expression is unaffected by corticosteroids in rat kidney, heart, and colon. Am J Physiol Cell Physiol 270: C1343C1353, 1996.

11. Farman N, Bonvalet JP. Aldosterone binding in isolated tubules. III. Autoradiography along the rat nephron. Am J Physiol Renal Fluid Electrolyte Physiol 245: F606-F614, 1983. 
12. Farman N, Bonvalet JP. Aldosterone binding in isolated tubules. IV Autoradiography along the nephron of the spontaneously hypertensive rat Am J Physiol Renal Fluid Electrolyte Physiol 249: F99-F106, 1985.

13. Farman N, Oblin ME, Lombes M, Delahaye F, Westphal HM, Bonvalet JP, Gasc JM. Immunolocalization of gluco- and mineralocorticoid receptors in rabbit kidney. Am J Physiol Cell Physiol 260: C226-C233, 1991.

14. Farman N, Rafestin-Oblin ME. Multiple aspects of mineralocorticoid selectivity. Am J Physiol Renal Physiol 280: F181-F192, 2001.

15. Farman N, Vandewalle A, Bonvalet JP. Autoradiographic determination of dexamethasone binding sites along the rabbit nephron. Am J Physiol Renal Fluid Electrolyte Physiol 244: F325-F334, 1983.

16. Fejes-Toth G, Pearce D, Naray-Fejes-Toth A. Subcellular localization of mineralocorticoid receptors in living cells: effects of receptor agonists and antagonists. Proc Natl Acad Sci USA 95: 2973-2978, 1998.

17. Frey FJ, Frey BM. Altered plasma protein-binding of prednisolone in patients with the nephrotic syndrome. Am J Kidney Dis 3: 339-348, 1984.

18. Funder J, Myles K. Exclusion of corticosterone from epithelial mineralocorticoid receptors is insufficient for selectivity of aldosterone action in vivo binding studies. Endocrinology 137: 5264-5268, 1996.

19. Gaeggeler HP, Gonzalez-Rodriguez E, Jaeger NF, Loffing-Cueni D, Norregaard R, Loffing J, Horisberger JD, Rossier BC. Mineralocorticoid versus glucocorticoid receptor occupancy mediating aldosteronestimulated sodium transport in a novel renal cell line. J Am Soc Nephrol 16: 878-891, 2005

20. Gaeggeler HP, Duperrex H, Hautier S, Rossier BC. Corticosterone induces 11 beta-HSD and mineralocorticoid specificity in an amphibian urinary bladder cell line. Am J Physiol Cell Physiol 264: C317-C322, 1993.

21. Garg LC, Knepper MA, Burg MB. Mineralocorticoid effects on Na-KATPase in individual nephron segments. Am J Physiol Renal Fluid Electrolyte Physiol 240: F536-F544, 1981.

22. Geering K, Claire M, Gaeggeler HP, Rossier BC. Receptor occupancy vs. induction of $\mathrm{Na}^{+}-\mathrm{K}^{+}$-ATPase and $\mathrm{Na}^{+}$transport by aldosterone. Am J Physiol Cell Physiol 248: C102-C108, 1985.

23. Geller DS, Rodriguez-Soriano J, Vallo Boado A, Schifter S, Bayer M, Chang SS, Lifton RP. Mutations in the mineralocorticoid receptor gene cause autosomal dominant pseudohypoaldosteronism type I. Nat Genet 19: 279-281, 1998

24. Gomez-Sanchez CE, de Rodriguez AF, Romero DG, Estess J, Warden MP, Gomez-Sanchez MT, Gomez-Sanchez EP. Development of a panel of monoclonal antibodies against the mineralocorticoid receptor. Endocrinology 147: 1343-1348, 2006

25. Gomez-Sanchez EP, Ahmad N, Romero DG, Gomez-Sanchez CE. Origin of aldosterone in the rat heart. Endocrinology 145: 4796-4802, 2004

26. Gomez-Sanchez EP, Venkataraman MT, Thwaites D, Fort C. ICV infusion of corticosterone antagonizes ICV-aldosterone hypertension. Am J Physiol Endocrinol Metab 258: E649-E653, 1990.

27. Hammond GL, Smith CL, Goping IS, Underhill DA, Harley MJ, Reventos J, Musto NA, Gunsalus GL, Bardin CW. Primary structure of human corticosteroid binding globulin, deduced from hepatic and pulmonary cDNAs, exhibits homology with serine protease inhibitors. Proc Nat Acad Sci USA 84: 5153-5157, 1987.

28. Hatae T, Ichimura T, Ishida T, Sakurai T. Apical tubular network in the rat kidney proximal tubule cells studied by thick-section and scanning electron microscopy. Cell Tissue Res 288: 317-325, 1997

29. Hoekstra D, Tyteca D, van IJzendoorn SC. The subapical compartment: a traffic center in membrane polarity development. J Cell Sci 117 2183-2192, 2004

30. Karim Z, Szutkowska M, Vernimmen C, Bichara M. Renal handling of $\mathrm{NH}_{3} / \mathrm{NH}_{4}^{+}$: recent concepts. Nephron Physiol 101: p77-p81, 2005.

31. Khadouri C, Marsy S, Barlet-Bas C, Doucet A. Short-term effect of aldosterone on NEM-sensitive ATPase in rat collecting tubule. Am J Physiol Renal Fluid Electrolyte Physiol 257: F177-F181, 1989.

32. Krozowski ZS, Rundle SE, Wallace C, Castell MJ, Shen JH, Dowling J, Funder JW, Smith AI. Immunolocalization of renal mineralocorticoid receptors with an antiserum against a peptide deduced from the complementary deoxyribonucleic acid sequence. Endocrinology 125: 192-198, 1989.

33. Lee SM, Chekal MA, Katz AI. Corticosterone binding sites along the rat nephron. Am J Physiol Renal Fluid Electrolyte Physiol 244: F504-F509, 1983.
34. Loffing J, Pietri L, Aregger F, Bloch-Faure M, Ziegler U, Meneton P, Rossier BC, Kaissling B. Differential subcellular localization of ENaC subunits in mouse kidney in response to high- and low-Na diets. Am J Physiol Renal Physiol 279: F252-F258, 2000

35. Loffing J, Vallon V, Loffing-Cueni D, Aregger F, Richter K, Pietri L, Bloch-Faure M, Hoenderop JG, Shull GE, Meneton P, Kaissling B. Altered renal distal tubule structure and renal $\mathrm{Na}^{+}$and $\mathrm{Ca}^{2+}$ handling in a mouse model for Gitelman's syndrome. J Am Soc Nephrol 15: 22762288, 2004

36. Loffing J, Zecevic M, Feraille E, Kaissling B, Asher C, Rossier BC, Firestone GL, Pearce D, Verrey F. Aldosterone induces rapid apical translocation of ENaC in early portion of renal collecting system: possible role of SGK. Am J Physiol Renal Physiol 280: F675-F682, 2001.

37. Lombes M, Farman N, Oblin ME, Baulieu EE, Bonvalet JP, Erlanger BF, Gasc JM. Immunohistochemical localization of renal mineralocorticoid receptor by using an anti-idiotypic antibody that is an internal image of aldosterone. Proc Natl Acad Sci USA 87: 1086-1088, 1990.

38. Lombes M, Kenouch S, Souque A, Farman N, Rafestin-Oblin ME. The mineralocorticoid receptor discriminates aldosterone from glucocorticoids independently of the 11 beta-hydroxysteroid dehydrogenase. Endocrinology 135: 834-840, 1994.

39. Marver D. Evidence of corticosteroid action along the nephron. Am J Physiol Renal Fluid Electrolyte Physiol 246: F111-F123, 1984.

40. Naray-Fejes-Toth A, Fejes-Toth G. Glucocorticoid receptors mediate mineralocorticoid-like effects in cultured collecting duct cells. Am J Physiol Renal Fluid Electrolyte Physiol 259: F672-F678, 1990.

41. Naray-Fejes-Toth A, Rusvai E, Fejes-Toth G. Minealocorticoid receptors and 11 beta-steroid dehydrogenase activity in renal principal and intercalated cells. Am J Physiol Renal Fluid Electrolyte Physiol 266: F76-F80, 1994

42. Nguyen Dinh Cat A, Ouvrard-Pascaud A, Tronche F, Clemessy M, Gonzalez-Nunez D, Farman N, Jaisser F. Conditional transgenic mice for studying the role of the glucocorticoid receptor in the renal collecting duct. Endocrinology 150: 2202-2210, 2009.

43. Nishi M, Ogawa H, Ito T, Matsuda KI, Kawata M. Dynamic changes in subcellular localization of mineralocorticoid receptor in living cells: in comparison with glucocorticoid receptor using dual-color labeling with green fluorescent protein spectral variants. Mol Endocrinol 15: 10771092, 2001.

44. Reyes AJ, Leary WP, Crippa G, Maranhao MF, Hernandez-Hernandez R. The aldosterone antagonist and facultative diuretic eplerenone: a critical review. Eur J Intern Med 16: 3-11, 2005.

45. Robertson NM, Schulman G, Karnik S, Alnemri E, Litwack G. Demonstration of nuclear translocation of the mineralocorticoid receptor (MR) using an anti-MR antibody and confocal laser scanning microscopy. Mol Endocrinol 7: 1226-1239, 1993

46. Ronzaud C, Loffing J, Bleich M, Gretz N, Grone HJ, Schutz G, Berger S. Impairment of sodium balance in mice deficient in renal principal cell mineralocorticoid receptor. J Am Soc Nephrol 18: 1679-1687, 2007.

47. Savory JG, Prefontaine GG, Lamprecht C, Liao M, Walther RF, Lefebvre YA, Hache RJ. Glucocorticoid receptor homodimers and glucocorticoid-mineralocorticoid receptor heterodimers form in the cytoplasm through alternative dimerization interfaces. Mol Cell Biol 21: 781-793, 2001

48. Schulz-Baldes A, Berger S, Grahammer F, Warth R, Goldschmidt I, Peters J, Schutz G, Greger R, Bleich M. Induction of the epithelial $\mathrm{Na}^{+}$ channel via glucocorticoids in mineralocorticoid receptor knockout mice. Pflügers Arch 443: 297-305, 2001.

49. Scrocchi LA, Hearn SA, Han VK, Hammond GL. Corticosteroidbinding globulin biosynthesis in the mouse liver and kidney during postnatal development. Endocrinology 132: 910-916, 1993.

50. Singer CJ, Khan MS, Rosner W. Characteristics of the binding of corticosteroid-binding globulin to rat cell membranes. Endocrinology 122: 89-96, 1988.

51. Stanton BA. Regulation by adrenal corticosteroids of sodium and potassium transport in loop of Henle and distal tubule of rat kidney. J Clin Invest 78: 1612-1620, 1986

52. Stone DK. Mineralocorticoid modulation of rabbit medullary collecting duct acidification. A sodium-independent effect. J Clin Invest 72: 77-83, 1983.

53. Todd-Turla KM, Schnermann J, Fejes-Toth G, Naray-Fejes-Toth A, Smart A, Killen PD, Briggs JP. Distribution of mineralocorticoid and glucocorticoid receptor mRNA along the nephron. Am J Physiol Renal Fluid Electrolyte Physiol 264: F781-F791, 1993. 
54. Tsuruoka S, Muto S, Taniguchi J, Suzuki M, Imai M. Effects of glucocorticoid and mineralocorticoid on potassium transport in the rat medullary thick ascending limb of Henle's loop. Kidney Int 47: 802-810, 1995.

55. Vandewalle A, Farman N, Bencsath P, Bonvalet JP. Aldosterone binding along the rabbit nephron: an autoradiographic study on isolated tubules. Am J Physiol Renal Fluid Electrolyte Physiol 240: F172-F179, 1981.

56. Verrey F, Hummler E, Schild L, Rossier B. Control of sodium transport by aldosterone. In: The Kidney, Physiology and Physiopathology, edited by Giebisch $G$ and Seldin D. Philadelphia, PA: Lippincott Williams \& Wilkins, 2000, p. 1441-1471.

57. Viengchareun S, Le Menuet D, Martinerie L, Munier M, Pascual-Le Tallec L, Lombes M. The mineralocorticoid receptor: insights into its molecular and (patho)physiological biology. Nucl Recept Signal 5: e012, 2007.

58. Wagner CA, Loffing-Cueni D, Yan Q, Schulz N, Fakitsas P, Carrel M, Wang T, Verrey F, Geibel JP, Giebisch G, Hebert SC, Loffing J. Mouse model of type II Bartter's syndrome. II. Altered expression of renal sodium- and water-transporting proteins. Am J Physiol Renal Physiol 294: F1373-F1380, 2008.

59. Willnow TE, Nykjaer A. Cellular uptake of steroid carrier proteinsmechanisms and implications. Mol Cell Endocrinol 316: 93-102.

60. Winter C, Schulz N, Giebisch G, Geibel JP, Wagner CA. Nongenomic stimulation of vacuolar $\mathrm{H}^{+}$-ATPases in intercalated renal tubule cells by aldosterone. Proc Natl Acad Sci USA 101: 2636-2641, 2004.

61. Work J, Jamison RL. Effect of adrenalectomy on transport in the rat medullary thick ascending limb. J Clin Invest 80: 1160-1164, 1987. 